\title{
Treasury Single Account: A Nudge towards Public Sector Accountability in Nigeria
}

\author{
Akinleye, G. T., Fajuyagbe S. B. \& Owoniya, B. 0 \\ Department of Accounting, Faculty of Management Sciences, Ekiti State University, Ado-Ekiti \\ gtakinleye@gmail.com,kolesamson@gmail.com,jide_muyiwa05@yahoo.com
}

\begin{abstract}
This study examined treasury single account, as a nudge towards public sector accountability in Nigeria. Specifically, the study analyzed the influence of adoption of treasury single account on the effectiveness of cash management, reduction of fraudulent activities and improvement in the level of accountability in the Nigerian public sector. The study made use of primary data collected through the use of a questionnaire, based on a sample of 400 respondents randomly selected from government parastatals, departments, institutions and ministries, across the six southwest states in Nigeria. Data collected were analyzed with frequency and percentage response analysis. The result showed that adoption of treasury single account provoked effective management of cash, sustained a considerable reduction in the level of fraudulent activities and aided improved level of accountability in the Nigerian public sector. Thus, there is no doubt that treasury single account is a nudge towards public sector accountability in Nigeria. Therefore, the government can further harness the potency of centralize control of public resources to birth a corrupt free society, where utmost accountability and transparency of resources mobilization and management can be attained.
\end{abstract}

Keywords: Treasury Single Account, Nudge, Public Sector Accountability, Nigeria

\section{Introduction}

Resources management among government ministries, departments and agencies are fundamental towards maintaining effective and efficient resources mobilization, and disbursement. At one time or the other, the means of ensuring that resources are managed and controlled effectively are being devised by government around the world to foster effective and efficient funding of projects and programmes in public sectors. This is because ensuring that all cash is collected in the right unit and the time frame is fundamental towards maintaining effective cash management among government ministries, departments and agencies (Helen, Amenawo \& Bassey, 2017). Maintaining unified and centralized control of government resources is fundamental to ensuring appropriate mobilization, allocation and management of government resources in any country of the world. Most developing countries (Nigeria inclusive), often lag behind in management of government resources for efficient public service delivery, due to the adoption of a fragmented system for resources mobilization, which is often devoid of centralized control. Inability to maintain centralized control of public resources mobilization has continued to impede accountability in most public sectors across the world. The need for the improved level of accountability and transparency in the management of government resources cannot be overemphasized in any country of the world. Without mincing words, the exigency of maintaining organized resources mobilization and management framework is on the increase.

In most developing countries including Nigeria thus provoking consideration for the adoption of single treasury account (Igbokwe-Ibeto, Nkomah, Osakede, \& Kinge, 2017; Ekubiat, \& Ime, 2016), Treasury single account (TSA) is a public accounting system under which all government revenue, receipts, income are collected into one single account. It is usually maintained by the country's Central Bank and all payments are made through this account. Treasury single account primarily ensures accountability of government revenue, enhance transparency and help avoid misappropriation of the fund (Nwaorgu, Ezenwaka, \& Onuorah, 2017). Essentially the need for the adoption of a treasury single account is often heralded by the existence of a lack of effective management of public resources, reflected in terms of fund misappropriation, lack of optimum transparency and accountability. Treasury single account (TSA) is an accounting policy that ensures adequate and efficient mobilization of public resources across all departments, ministries and agencies. Treasury single account tends to spur transparency and accountability in a government department, agencies and ministries, if well-structured and implemented (Igbokwe-Ibeto et al., 2016). As pointed out by Helen, Amenawo and Bassey (2017), Nigeria as a developing nation had over time struggled with the burgeoning rate of fund embezzlements in several quarters of the public sector, which ultimate was the sine-qua-non for the establishment of several control agencies including Code. 
Conduct Bureau, Independent Corrupt Practices Commission (ICPC), and Economic and Financial Crimes Commission (EFCC) to mention but few. Observably, activities of these agencies over time had little or no effect on the rate of financial crime in the country, with spiralling corrupt practices among public officers in recent times. In response to the perennial menace of poor public sector accountability and transparency in the country, it became necessary for government led by President Buhari to instigate the full adoption of treasury single account in the country, in an attempt to occasion substantial abatement of the inherent leakages in the mobilization process of public resources in the country. This study set out to assess treasury single account, as a nudge towards public sector accountability in Nigeria. This study specifically set out to investigate the efficacy of treasury single account towards sustaining public sector accountability in Nigeria, looking at how it adoption contributed to:

- Effective cash management in Nigerian public sector;

- Reduction in fraudulent activities in the Nigerian public sector;

- Improvement in the level of accountability in the Nigerian public sector;

\section{Literature Review}

The concept of Treasury Single Account: Treasury single account (TSA) can be defined as an allied structure of government bank accounts ensuring a combination of government funds and the best use of government possessions. TSA possess three crucial fundamentals, first a combined arrangement of government bank accounts that permits total control of all cash reserves, secondly an option suitable for accessing and working with TSA based on institutional arrangement and payment settlement method and Thirdly, the combination of government receipts not lacking anything that it needs to be complete as it should include all receipts including budgetary and extra-budgetary (Pattanayak \& Fainborn, 2010). This implies that every public receipt regardless of whether the matching cash flows are dependent on budgetary control or not (e.g. situations of earmarked funds, reserve funds and other off-budget or extra-budget funds) should be controlled by the TSA (Oguntodu, Alalade, Adekunle \& Adegbile, 2016; Shah, 2007). Treasury single account was perceived by Nelson, Adeoye \& Ogah, (2015). As an account that collates the balances of all the ministries, departments and agencies of the government, but there is an intermediate account for every MDAs that holds the total of the expenditures and receipts. In this way, the complete amount will be transferred in the end to the treasury single account.

The treasury single account can also be seen as a unified arrangement of government bank accounts enabling a combination of revenues from all MDAs and advantageous use of government monetary resources (Onyekpere, 2015). As posited by Oguntodu et al. (2016) treasury single account is a set of connected bank accounts that control the receipts and payments of the government and ensures a consolidated view of government monetary worth at any point in time. The merits of this account are many. The collection of revenues into a single treasury account makes it possible for prompt capture and payment of all revenues received into the government's account without the multiple banking structures impeding a smoothoperation. This merit in this way limits revenue leakages that results into revenue loss and lack of accountability and transparency in public sectors (Oguntodu et al., 2016). The broad objective of treasury single account is to enhance successful control of government monetary balances. Specifically, treasury single account fulfils the following objectives:

- Reduces transaction expenses during budget execution;

- Limits the delay in dispense of revenue to the government;

- Enhance quick payments of government expenditures;

- Effective control and monitoring of the sharing of funds to different government agencies;

- Enhances easy coordination with the monetary policy operation;

Public Sector Accountability: Accountability is connected with being responsible to the owners who put some trust, faith and resources in charge of someone (Nwaorgu, Ezenwaka \& Onuorah, 2017). Accountability is ensuring that assigned duties or obligations are carried out, in accordance with stated rules, standards and regulations that can guaranty expected outcome or overall performance. It implies doing things clearly in line 
with the due process, sense of feedback accuracy. In ethics and governance, accountability is the act of being responsible and worthy of recognition for the successful discharge of an obligation. Accountability is the acceptance of answerability for actions, decisions taken in the process discharging delegated tasks (Nwaorgu, Ezenwaka \& Onuorah, 2017).

Treasury Single Account and Public Sector Accountability in Nigeria: A Central system of banking according to Stephen, (2016) is crucial for sustaining effective control and management of public resources in developing country like Nigeria. Success of treasury single account in its achievement of efficient management of fund primarily in the public sector necessitated the need for a total collaboration of the stakeholders (Central Bank of Nigeria (CBN), Federal and State Accountants-General, Ministries, Departments and Agencies (MDAs), and the Deposit Money Banks) during the pre-implementation, implementation and post-implementation stages of the development (CBN, 2015). As relayed by Igbokwe-Ibeto, Nkomah, Osakede \& Kinge (2017), adoption of treasury single account in Nigeria had hither-to aided Nigerian government in maintaining effective management of resources across public establishments. The introduction of the TSA has enhanced fiscal discipline, efficiency and accountability of the government. This restricted access to public funds has led to efficient use of public funds coupled with innovative and profit-yielding public investment in the important development sectors of the country (Mboto, Offiong \& Ibor, 2017).

Empirical Evidence: Helen, Amenawo and Bassey (2017) investigated the public perception of the treasury single account in Nigeria. Specifically, the study focused on the degree of public perception and acceptance of the policy treasury single account in MDAs. The study collected data from 190 respondents in Calabar, Cross River. The study analysed data using Chi-square technique. The study revealed a significant acceptance of Treasury Single Accounts in Calabar. Also, the study discovered the negative and significant impact of public perception on treasury single account. The study therefore concluded that there are acceptance and well perception of treasury single account in Nigeria. However, the study viewed ill-timed and lack of pre-launch preparation of operation modus which lead to hardship and gross systematic inefficiency. Thus, the study recommended that the government should organize seminars and workshops for account-holding MDA's on the advantages of treasury single Account. Ekubiat and Ime (2016) examined the adoption of Treasury Single Account (TSA) by the state government of Nigeria the study specifically investigated benefits, challenges and prospects of Treasury Single accounts by the state government. The study collected data from 133 ICAN and ANAN members in different sectors of Akwa Ibom state. The study analysed data using descriptive analysis and t-test statistics. The study found a significant benefit of formulation and execution of treasury single account by the state government. However, the study discovered that adoption of Treasury Single Account is minimal in Nigerian states. Thus, the study recommended the need for state government to enlightened stakeholders on the benefit of TSA adoption. Igbokwe-Ibeto, Nkoma, Osakede and Kinge (2017) assessed treasury Single Account in Nigeria. Specifically, the study evaluated the significance of treasury single account in promoting transparency and accountability of public sectors finance.

The study employed the discursive method. The study revealed, among others, improved appropriation control, improved operational control during budget execution, efficient cash management and improved bank reconciliation and quality of fiscal data as benefits of TSA adoption. However, the study discovered that TSA adoption led to the loss of a job in commercial banks that rely on government accounts. Therefore, the study concluded that the significance of the adoption of TSA in Nigeria mixture of good, bad and ugly. Thus, the study recommended the legal framework on TSA should be reviewed and amended; organize training for relevant CBN and MDAs staff; and adoption of TSA should progress slowly and wisely. Igbekoyi and Agbaje (2017) assessed the implication of treasury single account adoption on the public sector accountability and transparency. Specifically, the study examined the effect of TSA on financial leakages, transparency in the administration of public funds and financial appropriation. The study extracted data on 100 respondents from10 MDAs in Nigeria. The study analysed data using ANOVA. The study discovered that TSA possessed a significant effect on financial leakages and financial misappropriation. Also, the study found that TSA has a significant impact on accountability and transparency through consolidated revenue received and centralized revenue pool whereas TSA has an insignificant impact on budgetary control. Nwarorgu, Ezenwaka and Onuorah (2017) examined treasury single accounting and public sector in Nigeria. The study specifically, assessed the degree of influence of regular monitoring of government cash balances and unexpected fiscal 
volatility on accountability in the Public sector. The study collected data from 250 staff in the accounting department of four federal government health institutions.

The study analyzed data using the ordinary least square technique. The study discovered that regular monitoring of government cash balance influence greatly accountability in the public sector, given the coefficient of determination of 0.82 . Also, the study revealed that the impact of unexpected fiscal volatility on accountability is on the average, given the coefficient of determination of 0.49 . Therefore, the study concluded that TSA reduces financial leakages in revenue generation and promotes transparency and accountability in Public sectors. Thus, the study recommended that the government should enlighten the public on the benefit of the policy of TSA. Ndubuaku, Ohaegbu, and Nina (2017) analyzed the impact of treasury single account on the performance of the banking sector in Nigeria. Specifically, the study examined the impact of Federal Government deposit on credit to the private sector; on deposit mobilization; and loans and advances. The study collated data over the period of 2002-2014 for 24 banks in Nigeria. The study analysed data using least square regression method. The study discovered the positive and significant impact of federal government deposit on credit to the private sector, deposit mobilization and loan and advances. Therefore, the study concluded that TSA has a significant influence on the performance of banking sectors in Nigeria. Thus, the study recommended that banks should avoid over-reliance on government deposit and seek funds from other sectors of the economy. Onuorah (2016) assessed federal government treasury single account deposit and commercial bank performance. The study specifically, analysed the impact of federal government treasury single account deposit on bank performance.

The study employed return on equity and return on investment as proxies for the dependent variable, bank performance. Federal government demand deposit, federal government time deposit and federal government savings deposit were used as a measure for an explanatory variable, federal government treasury single deposit account. The study collated data over the period 2012-2016. The study analysed data using the least square technique. The study found that federal government demand deposit has a negative impact on bank performance whereas federal government time and savings deposit have a positive impact on bank performance. Also, the study revealed that the impact of these deposits is less effective on bank performance as shown by the coefficient of determination of 0.23 . Therefore, the study recommended that the government should ensure an adequate working system of TSA for effective performance in the banking sector. Yusuf (2016) evaluated the effects of treasury single account on public management in Nigeria. Specifically, the study analysed the degree of influence of treasury single account on financial leakage reduction and the promotion of accountability and transparency in public sector financial management. The study extracted data from 72 respondents in MDAs within Bauchi metropolis. The study analysed data using Pearson Moment Correlation Coefficient. The study revealed that a positive and significant relationship between treasury single account and financial leakages, accountability and transparency. Okerekeoti and Okoye (2017) studied treasury single account in Nigeria: The study specifically, examined the workings of treasury single account in Nigeria. The study employed a discursive approach. The study showed that treasury single account reduces financial leakages, promotes accountability and transparency. Also, the study explained that treasury single account encourages timely payment and capturing of revenues that enter government treasury.

Akujuru and Eyioku (2017) analyzed the effect of treasury single account policy on corruption in Nigeria. Specifically, the study examined the extent of the impact of TSA on corruption, financial leakages, accountability and transparency in the public sector financial management. The study employed data collected on 366 respondents from MDAs in Port Harcourt. The study analyzed data using the percentage method. The study revealed that treasury single account has reduced corruption, blocked financial leakages and promote accountability and transparency in public sector financial management to a large extent. However, the study revealed that effectiveness and efficiency of TSA have been limited by bureaucracy, government inaction and actions, internet platform delay among others. Thus, the study recommended, among others, that government should secure appropriate legislative support to facilitate the relevant regulatory environment. Oguntolu, Alalade, Adekunle and Adeigbe (2016) assessed treasury single account and Nigeria's economy. Specifically, the study analyzed the benefit of TSA government revenue, TSA government expenditure and TSA commercial banks on gross domestic product. TSA government revenue was captured by deposit with CBN, TSA government expenditure was measured by credit with CBN and TSA commercial bank was proxied by money supply. The study employed data covering the period of 199-2015. 
The study analyzed data using the ordinary least square technique. The study revealed that credit and deposit with CBN as well as money supply have a positive impact on the gross domestic product. However, the study discovered that the effect of deposit with CBN on the gross domestic product was insignificant.

\section{Methodology}

This study made use of primary data sourced from 400 randomly selected respondents from government parastatals, agencies and ministries across six southwest states in Nigeria. The study made use of structured questionnaire designed in two sections, which captures respondent's details, and responses to questions related to the contribution of TSA adoption to effective cash management, reduction of fraudulent activities and improvement in the level of accountability in selected parastatals, agencies and ministries. Data collected in the study were analyzed with the use of percentage and frequency count.

\section{Result and Discussion}

Table 1: Respondents Details (Distribution of Respondents by Sex, Length of Service, Management Level and Category of Establishment)

\begin{tabular}{|c|c|c|c|}
\hline Variable & Detail & Frequency & Percentage \\
\hline \multirow[t]{3}{*}{ Sex } & Male & 216 & 54.0 \\
\hline & Female & 184 & 46.0 \\
\hline & Total & 400 & 100.0 \\
\hline \multirow[t]{5}{*}{ Length of Service } & Below 5 Years & 168 & 42.0 \\
\hline & 6-10 Years & 144 & 36.0 \\
\hline & 11-15 Years & 24 & 6.0 \\
\hline & Above 15 Years & 64 & 16.0 \\
\hline & Total & 400 & 100.0 \\
\hline \multirow[t]{4}{*}{ Management level } & $\begin{array}{l}\text { Top Level Management } \\
\text { staff }\end{array}$ & 72 & 18.0 \\
\hline & $\begin{array}{l}\text { Middle Level } \\
\text { Management staff }\end{array}$ & 272 & 68.0 \\
\hline & $\begin{array}{l}\text { Low Level Management } \\
\text { staff }\end{array}$ & 56 & 14.0 \\
\hline & Total & 400 & 100.0 \\
\hline \multirow[t]{6}{*}{ Establishment category } & Ministries & 48 & 12.0 \\
\hline & Departments & 16 & 4.0 \\
\hline & Agencies & 48 & 12.0 \\
\hline & Institutions & 240 & 60.0 \\
\hline & Others & 48 & 12.0 \\
\hline & Total & 400 & 100.0 \\
\hline
\end{tabular}

Source: Authors' Computation, (2018).

Table 1 revealed that 216(54\%) of the respondents sampled in the study are male, $184(46 \%)$ are female, length of service $168(42 \%)$ of the respondents is less than 5 years, that of $144(36 \%)$ is between $6-10$ years, that of $24(6 \%)$ is between $11-15$ years, while that of $64(16 \%)$ is above 15 years. The table also reported distribution of the respondents by management level, showing that $72(18 \%)$ are top-level management staff, $272(68 \%)$ are middle level management staff, while 56(14\%) are low-level management staff, with distribution by categories of establishment showing $48(12 \%)$ for ministries, $16(4 \%)$ for departments, $48(12 \%)$ for agency, $240(60 \%)$ for institutions, and $48(12 \%)$ for others.

Treasury Single Account Adoption and Effective Cash Management in Nigeria Public Sector: This section presents perception analysis of the contribution of TSA adoption to effective cash management in Nigerian public sector, based on the perception of stakeholders sampled from the public office across Nigeria. The analysis is presented in table 2 and figure 1 below 
Table 2: Analysis of TSA Adoption and Effective Cash Management in Nigeria Public Sector

\begin{tabular}{|c|c|c|c|c|c|c|}
\hline S/N & QUESTIONS & SA & $\mathbf{A}$ & UD & D & SD \\
\hline 1 & $\begin{array}{l}\text { Treasury Single Account (TSA) is } \\
\text { an effective strategy for } \\
\text { sustaining efficient cash } \\
\text { management in Nigeria public } \\
\text { sector }\end{array}$ & $232(58 \%)$ & $152(38 \%)$ & $0(0 \%)$ & $0(0 \%)$ & $16(4 \%)$ \\
\hline 2 & $\begin{array}{l}\text { Treasury Single Account (TSA) is } \\
\text { useful for reducing cash } \\
\text { management competition in } \\
\text { Nigeria Public sector }\end{array}$ & $96(24 \%)$ & $200(50 \%)$ & $72(18 \%)$ & $32(8 \%)$ & $0(0 \%)$ \\
\hline 3 & $\begin{array}{l}\text { Receipt and disbursement of } \\
\text { government resources has been } \\
\text { effective since the adoption of } \\
\text { Treasury Single Account (TSA) }\end{array}$ & $112(28 \%)$ & $160(40 \%)$ & $88(22 \%)$ & $32(8 \%)$ & $8(2 \%)$ \\
\hline 4 & $\begin{array}{l}\text { There is high level of efficiency in } \\
\text { fund mobilization in public sector } \\
\text { since the adoption of Treasury } \\
\text { Single Account (TSA) }\end{array}$ & $96(24 \%)$ & $128(32 \%)$ & $96(24 \%)$ & $64(16 \%)$ & $16(4 \%)$ \\
\hline 5 & $\begin{array}{l}\text { Adoption of Treasury Single } \\
\text { Account (TSA) has significantly } \\
\text { reduce bank's fees and } \\
\text { transaction cost in Nigeria public } \\
\text { sector }\end{array}$ & $80(20 \%)$ & $112(28 \%)$ & $128(32 \%)$ & $64(16 \%)$ & $16(4 \%)$ \\
\hline
\end{tabular}

Source: Authors' Computation, (2018).

Figure 1: Analysis of TSA Adoption and Effective Cash Management in Nigeria Public Sector

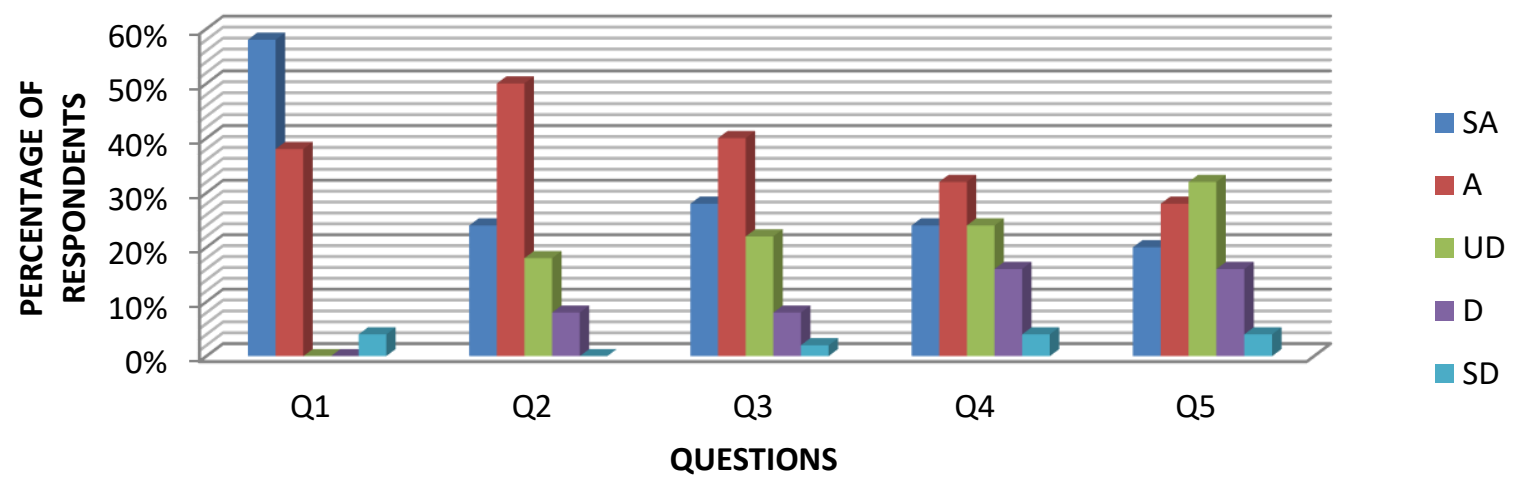

Table 2 and figure1 revealed the contribution of treasury single account adoption to effective cash management in Nigeria public sector. As reported in the table, $96 \%$ (58\% strongly agreed and 38\% agreed) of the respondent support the claim that Treasury Single Account (TSA) is an effective strategy for sustaining efficient cash management in Nigeria public sector, 74\% (24\% strongly agreed and 50\% agreed) acclaimed that Treasury Single Account (TSA) is useful for reducing cash management competition in Nigeria Public sector, in the opinion of $68 \%$ ( $28 \%$ strongly agreed and $40 \%$ agreed) of the respondents, Receipt and disbursement of government resources has been effective since the adoption of Treasury Single Account (TSA), while $56 \%$ (24\% strongly agreed and $32 \%$ agreed) of the respondents consent to the claim that there is high level of efficiency in fund mobilization in the public sector since the adoption of the Treasury Single Account (TSA), and finally about $48 \%$ (20\% strongly agreed and $28 \%$ agreed) of the respondents agreed that Adoption of Treasury Single Account (TSA) has significantly reduced bank's fees and transaction cost in Nigeria public sector, as against $20 \%$ that disagreed. Hence this analysis reflects that to a large extent, the adoption of treasury single account as culminated into effective cash management in Nigerian public sector. 
Treasury Single Account (TSA) Adoption and Reduction of Fraudulent Activities in Nigeria Public Sector: This section presents perception analysis of the contribution of TSA adoption to a reduction in fraudulent activities in Nigerian public sector, based on the perception of stakeholders sampled from the public office across Nigeria. The analysis is presented in table 3 and figure 2 below

Table 3: Analysis of TSA Adoption and Reduction of Fraudulent Activities in Nigeria Public Sector

\begin{tabular}{|c|c|c|c|c|c|c|}
\hline S/N & QUESTIONS & SA & $\bar{A}$ & UD & D & SD \\
\hline 1 & $\begin{array}{l}\text { Treasury Single Account (TSA) had } \\
\text { hither-to enhanced oversight and } \\
\text { control of government resources }\end{array}$ & $96(24 \%)$ & $168(42 \%)$ & $80(20 \%)$ & $48(12 \%)$ & $8(2 \%)$ \\
\hline 2 & $\begin{array}{l}\text { Adoption of Treasury Single } \\
\text { Account (TSA) has significantly } \\
\text { improved operational control } \\
\text { during budget execution in Nigeria } \\
\text { public sector }\end{array}$ & $112(28 \%)$ & $168(42 \%)$ & 64 (16\%) & $48(12 \%)$ & $8(2 \%)$ \\
\hline 3 & $\begin{array}{l}\text { Adoption of Treasury Single } \\
\text { Account (TSA) has substantially } \\
\text { reduce the liquidity reserve need } \\
\text { in Nigeria publics sector }\end{array}$ & $72(18 \%)$ & $200(50 \%)$ & 64 (16\%) & $56(14 \%)$ & $8(2 \%)$ \\
\hline 4 & $\begin{array}{l}\text { Adoption of Treasury Single } \\
\text { Account (TSA) has significantly } \\
\text { reduce misappropriation and } \\
\text { diversion of public funds }\end{array}$ & $144(36 \%)$ & 192 (48\%) & $40(10 \%)$ & $16(4 \%)$ & $8(2 \%)$ \\
\hline 5 & $\begin{array}{l}\text { Adoption of Treasury } \\
\text { Account (TSA) position } \\
\text { public sigeria } \\
\text { performance and } \\
\text { efficiency }\end{array}$ & $152(38 \%)$ & $176(44 \%)$ & $40(10 \%)$ & $24(6 \%)$ & $8(2 \%)$ \\
\hline
\end{tabular}
Source: Authors' Computation, (2018).

Figure 2: Analysis of TSA Adoption and Reduction of Fraudulent Activities in Nigeria Public Sector

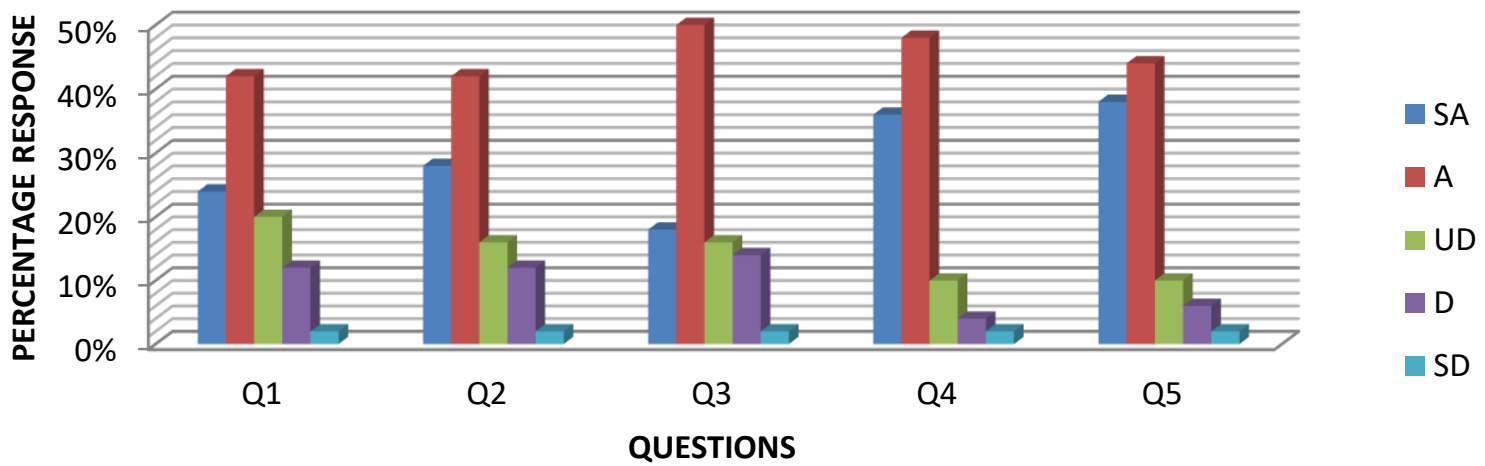

Table 3 and figure 2 showed the contribution of treasury single account adoption to the reduction of fraudulent activities in Nigeria public sector, as acclaimed by $66 \%$ (24\% strongly agreed and $42 \%$ agreed) of the respondents Treasury Single Account (TSA) had hither-to enhanced oversight and control of government resources, $70 \%$ (28\% strongly agreed and $42 \%$ agreed)of the respondent confirmed that adoption of Treasury Single Account (TSA) has significantly improved operational control during budget execution in Nigeria public sector, in the opinion of $68 \%$ (18\% strongly agreed and $50 \%$ agreed) of the respondents adoption of Treasury Single Account (TSA) has substantially reduce the liquidity reserve need in Nigeria publics sector, $84 \%$ (36\% strongly agreed and $48 \%$ agreed) of the respondents submitted that adoption of Treasury Single Account (TSA) has significantly reduced misappropriation and diversion of public funds, and 
82\% (38\% strongly agreed and 44\% agreed) agreed that adoption of Treasury Single Account (TSA) position Nigeria public sector for better performance and operational efficiency. In a nutshell, the analysis presented in table 3 and figure 2 reflects that adoption of treasury single account has led to considerable reduction of fraudulent activities in Nigeria public sector.

Treasury Single Account (TSA) Adoption and Improvement in the Level of Accountability in Nigeria Public Sector: This section presents perception analysis of the contribution of TSA adoption to improvement in the level of accountability in Nigerian public sector, based on the perception of stakeholders sampled from public offices across Nigeria. The analysis is presented in table 4 and figure 3 below:

Table 4: Analysis of TSA Adoption and Improvement in the Level of Accountability in Nigeria Public Sector

\begin{tabular}{|c|c|c|c|c|c|c|}
\hline $\mathbf{S} / \mathbf{N}$ & QUESTIONS & SA & $\mathbf{A}$ & UD & D & SD \\
\hline 1 & $\begin{array}{l}\text { Treasury Single Account (TSA) is a } \\
\text { potent tool for reducing excessive } \\
\text { spending in Nigeria public sector }\end{array}$ & $152(38 \%)$ & $184(46 \%)$ & $32(8 \%)$ & $24(6 \%)$ & $8(2 \%)$ \\
\hline 2 & $\begin{array}{l}\text { Introduction of Treasury Single } \\
\text { Account (TSA) has significantly } \\
\text { help in checking institutional } \\
\text { leakages in Nigerian public sector }\end{array}$ & $184(46 \%)$ & $184(46 \%)$ & $8(2 \%)$ & $16(4 \%)$ & $8(2 \%)$ \\
\hline 3 & $\begin{array}{l}\text { Adoption of Treasury Single } \\
\text { Account (TSA) contribute } \\
\text { significantly to smooth accounting } \\
\text { practices in Nigeria public sector }\end{array}$ & $128(32 \%)$ & $176(44 \%)$ & $56(14 \%)$ & $32(8 \%)$ & $8(2 \%)$ \\
\hline 4 & $\begin{array}{l}\text { Adoption of treasury Single } \\
\text { Account(TSA) has hither-to foster } \\
\text { resourceful utilization of } \\
\text { government fund }\end{array}$ & $104(26 \%)$ & $144(36 \%)$ & $88(22 \%)$ & $56(14 \%)$ & $8(2 \%)$ \\
\hline 5 & $\begin{array}{l}\text { The level of accountability and } \\
\text { transparency had significantly } \\
\text { increased in Nigeria public sector } \\
\text { since the adoption of Treasury } \\
\text { Single Account (TSA) }\end{array}$ & $80(20 \%)$ & $240(60 \%)$ & $48(12 \%)$ & $24(6 \%)$ & $8(2 \%)$ \\
\hline
\end{tabular}

Source: Authors' Computation, (2018).

Figure 3: Analysis of TSA Adoption and Improvement in the Level of Accountability in Nigeria Public Sector



Table 4 and figure 3 contribution adoption of treasury single account to the improvement in the Level of Accountability in Nigeria Public Sector. As presented in the table 84\% (38\% strongly agreed and 46\% agreed) of the respondent consent to that claim that Treasury Single Account (TSA) is a potent tool for reducing 
excessive spending in Nigeria public sector, 92\% (46\% strongly agreed and 46\% agreed) of the respondents submitted that introduction of Treasury Single Account (TSA) has significantly help in checking institutional leakages in Nigerian public sector, in the opinion of $76 \%$ (32\% strongly agreed and $44 \%$ agreed) of the respondents adoption of Treasury Single Account (TSA) contribute significantly to smooth accounting practices in Nigeria public sector, 62\% (26\% strongly agreed and 36\% agreed) of the respondent agreed that adoption of treasury Single Account(TSA) has hither-to foster resourceful utilization of government fund, and $80 \%$ (20\% strongly agreed and $60 \%$ agreed) of the respondents submitted that the level of accountability and transparency had significantly increased in Nigeria public sector since the adoption of Treasury Single Account (TSA). Hence this analysis revealed that adoption of treasury single account had provoked improvement in the level of public sector accountability in Nigeria.

\section{Conclusion and Recommendation}

Based on the findings of the study, it is concluded that the adoption of treasury single account has provoked effective management of cash in Nigerian public sector, sustained a considerable reduction in the level of fraudulent activities and aid improved level of accountability. Hence, there is no doubt that treasury single account is a nudge towards public sector accountability in Nigeria. It thus stands that government can further harness the potency of central control of the public resource, to birth a corrupt free society, where utmost accountability and transparency of resources mobilization, allocation and disbursement can be sustained. Discoveries made in this study is in congruence with the submission, conclusion and/or position of previous studies such as Igbekoyi and Agbaje (2017), Nwarorgu, Ezenwaka and Onuorah (2017), Ndubuaku, Ohaegbu, and Nina (2017), Yusuf (2016), Okerekeoti and Okoye (2017), Akujuru and Eyioku (2017) on the discourse of the role of treasury single account in sustaining public sector accountability.

\section{References}

Akujuru, C. A. \& Eyioku, N. C. (2017). Effect of treasury single account policy on corruption in Nigeria.

CBN. (2015). Revised guidelines for compliance with treasury single account by banks in Nigeria. Abuja: Central Bank of Nigeria.

Ekubiat, J. U. \& Ime, E. E. (2016). Adoption of Treasury Single Account (TSA) by the state government of Nigeria: benefits, challenges and prospects. Journal of Finance and Accounting, 4(3), 126-130.

Helen, W. M., Amenawo, I. O. \& Bassey, I. I. (2017). Public perception of the treasury single account in Nigeria. Journal of Economics and Development Studies, 5(2), 68-77.

Igbekoyi, O. E. \& Agbaje, W. H. (2017). An assessment of the implication of treasury single account adoption on the public sector accountability and transparency. European Journal of Auditing and Finance Research, 5(8), 33-49.

Igbokwe-Ibeto, C. J., Nkoma, B. B., Osakede, K. O. \& Kinge, R. F. (2016). Treasury Single Account- transparency and accountability in Public finance management in Nigeria: The Journey so far. Africa's Public Service Delivery and Performance Review, 342-359.

Igbokwe-Ibeto, C. J., Nkomah, B. B., Osakede, K. O. \& Kinge, R. F. (2017). Treasury Single Account Transparency and Accountability in Public Finance Management in Nigeria: The Journey So Far. A published Article, 342-359.

Mboto, W. M., Offiong, A. I. \& Ibor, B. I. (2017). Public Perception of the Treasury Single Account in Nigeria. Journal of Economics and Development Studies, 5(2), 68-77.

Ndubuaku, V. C., Ohaegbu, O. K. \& Nina, N. M. (2017). Impact of treasury single account on the performance of the banking sector in Nigeria. IOSR Journal of Economics and Finance, 8(4), 8-15.

Nelson, C., Adeoye, T. \& Ogah, D. (2015). Treasury Single Account (TSA): Giving Life to Jonathan's 'Dead' Policy Directive. The Guardian Newspaper, 16, 52-58.

Nwarorgu, I. A., Ezenwaka, F. A. \& Onuorah, J. (2017). Treasury single accounting and public sector in Nigeria. Journal of Economics, Management and Trade, 19(4), 1-8.

Oguntodu, J. A., Alalade, Y. S. A., Adekunle, Y. A. \& Adegbile, F. F. (2016). Treasury Single Account and Nigeria's Economy Between 1999 and 2015: An Assessment. Journal of Accounting and Financial Management, $2(6), 61-75$. 


\section{Journal of Economics and Behavioral Studies (ISSN: 2220-6140)}

Vol. 10, No. 6, pp. 201-210, December 2018

Oguntolu, J. A., Alalade, Y. S. A., Adekunle, Y. A. \& Adeigbe, F. F. (2016). Treasury single account and Nigeria's economy between 1999 and 2015: An assessment. Journal of Accounting and Financial Management, 2(6), 61-75.

Okerekeoti, C. U. \& Okoye, E. I. (2017). Treasury Single Account (TSA) In Nigeria: A Theoretical Perspective. The 2017 International Conference on African Entrepreneurship and Innovation for Sustainable Development (AEISD), 558-576.

Onuorah, A. C. (2016). Federal government treasury single account deposit and commercial bank performance. Journal of Social and Management Sciences, 11(3), 1-13.

Onyekpere, L. (2015). Buhari Orders Federal Ministries, Agencies to open treasury single account (TSA). The Punch Newspaper, August 9.

Pattanayak, S. \& Fainboim, I. (2010). Treasury Single Account: Concept, Design and Implementation Issues. International Monetary Fund Working Paper \#10/143, Research, 5(1), 43-53.

Shah, A. (2007). Local Public Financial Management: Public Sector Governance and Accountability Series. The World Bank Working Paper.

Stephen, A. (2016). Treasury Single Account Policy and Government Revenue in Nigeria: Journal of Internet Banking and Commerce, 12(4), 53-57.

Yusuf, M. B. (2016). Effects of treasury single account on public management in Nigeria. Research Journal of Finance and Accounting, 7(6), 164-170. 